\title{
Erratum: The structure of Ezra-Nehemiah as a literary unit
}

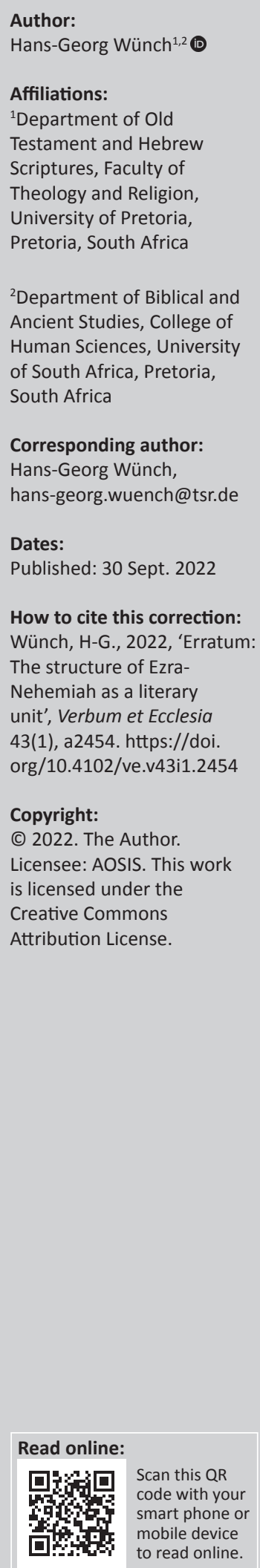

Scan this QR code with your smart phone or

In the published article, Wuench, H-G., 2021, 'The structure of Ezra-Nehemiah as a literary unit', Verbum et Ecclesia 42(1), a2317. https://doi.org/10.4102/ve.v42i1.2317, the author's name was incorrectly spelt as Hans-Georg Wuench. The correct spelling is Hans-George Wünch.

The publisher apologises for this error. The correction does not change the significance of study's findings or overall interpretation of its results or the scientific conclusions of the article in any way. 


\section{The structure of Ezra-Nehemiah as a literary unit}

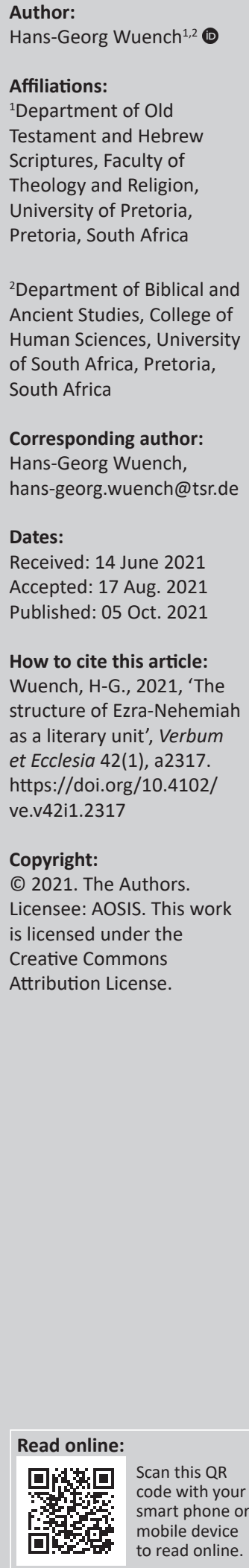

The OT books, Ezra and Nehemiah, are to be considered as one book. This is more or less the common conviction of most OT scholars today. However, their redaction process raises many questions. What is their relation to the book of Chronicles, and how is their actual structure to be understood? Why do we find two almost identical lists of returnees from exile in Ezra 2 and Nehemiah 7? What about the differences between these lists? This article understands the structure of Ezra-Nehemiah as a consciously created literary unit, where the two lists of returnees serve as an important part of the literary structure. The author works on the assumption of the so-called new literary criticism, understanding the narrative in the book on a synchronic basis. He shows that the book of Ezra-Nehemiah can indeed be understood as one literary unit, and that the two lists of returnees function as a literary means to structure the book. There is therefore no need to 're-organise' the narrated events in Ezra-Nehemiah according to an alleged different chronological order.

Intradisciplinary and/or interdisciplinary implications: The study argued for a canonical and synchronic approach to biblical narratives. The biblical texts should be understood as consciously created narratives, where the apparent discrepancies are important aspects of the narrative fixture.

Keywords: OT; Ezra-Nehemiah; structure; synchronic exegesis; exile; Chronicles and Ezra-Nehemia; narratology; literary criticism.

\section{Introduction}

Anyone who starts reading the Book of Ezra will be surprised by its content. Ezra is not mentioned prior to chapter 7 . The book starts with the edict of the Persian king, Cyrus (550-530 BC), and a very detailed list of returnees from the Babylonian exile. It speaks about Jeschua and Serubbabel as the leaders of this group of returnees, and the problems they all had when returning to Israel. It then tells about the start of rebuilding the temple in Jerusalem, and the problems they had with the people already living in the land. It is only in chapter 7 that Ezra appears, which is in the last third part of the book. At that time, Arthasasta was the king of Persia. If Arthasasta could be identified as Artaxerxes I (which many exegetes believe), these events occurred roughly 100 years after the return from exile. If one further reads Nehemiah, one will suddenly find Ezra again (in chapters 8 and 12), where he also plays an important role.

This seems to be confusing. How do these two books belong together? Who wrote them? Why do we call the first book the Book of Ezra, even though he is not the most prominent figure in it, and a major part of the narratives took place long before Ezra was born? When it then comes to Nehemiah 7, one finds the same list of returnees (with some discrepancies) as in Ezra 2. And if one finally tries to reconstruct the events narrated in the two books, one will inevitably stumble about Nehemiah 8 , because the events in this chapter do not seem to fit after the events narrated in Nehemiah 1-7.

This article aims to look at some of these questions. The main focus is on the composition and literary structure of the Books of Ezra and Nehemiah. The article starts with a close look at the books themselves. Thereafter follows a discussion as to whether or not they are to be considered as two books or as one book, and consequently, as one literary unit. Before doing this, two introductory remarks concerning the theological standpoint of the author of this article are necessary.

The author's background clearly is a conservative one. He approaches biblical texts with an attitude of trust, not of critical distrust, as it seems to be so prominent, especially among Western theological researchers. The goal is to understand the text as it is, and to see if the claims of the text 
can be understood as true. The first approach to difficulties or discrepancies would therefore be to try to harmonise them or to show ways, how they can be harmonised. This, of course, does not solve every problem with OT texts, but in many cases, there are indeed possible ways to understand the biblical texts as fitting into the contexts.

This background leads to the second remark concerning the methodology used. The main interest of the author is to understand the literary structure of texts as deliberately composed literary unities, using the methodology of new literary criticism or literary approach, also known as synchronic exegesis. In Germany, this is often called 'literaturwissenschaftliche Exegese'. This methodology, which was first developed by scholars such as Robert Alter (2011) in the USA, and Shimon Bar-Efrat in Israel (Bar-Efrat, Menzel \& Naumann 2006), was recently formulated in Germany by Helmut Utzschneider and Stefan Ark Nitsche in their book Arbeitsbuch literaturwissenschaftliche Bibelauslegung (Utzschneider \& Nitsche 2014). The main idea behind this methodology is that the biblical texts are consciously created literary unities, even though we may identify discrepancies in the text itself. These differences and even discrepancies, very often play an important role in the understanding of the text. Literary exegesis does not ignore the questions of the development of the text, its 'Sitz im Leben', or the sources used in compiling the text (so-called diachronic exegesis), but it works on the assumption that the author or redactor of the text purposefully used his sources, and the differences between them, in his compilation, and that these differences play an important role when trying to understand the text. As Blenkinsopp (1988) wrote:

Concern for what Childs calls the canonical shaping of the material requires that we try to understand the present order and arrangement before engaging in critical deconstruction and reconstruction. (p. 41)

By only looking at the differences or the presumed stages of development, one tends to overlook precisely these elements of the text. In his discussion of the relation between Genesis 1 and 2, Rolf Rendtorff, for example, pleads for an understanding of the two chapters, not as two different and even contradictory narratives of creation, but as a literary unit, which can only be fully understood when read together. Rendtorff (1984) then wrote:

Es erscheint fraglich, ob es ein Gewinn für die theologische Auslegung dieser und anderer Texte ist, wenn durch die historisch-kritische Auslegung Schwierigkeiten geschaffen werden, die davor nicht bestanden. (p. 288)

For Ezra and Nehemiah, this means that the main questions of this article are: if these texts can be read as a literary unit, and if the apparent differences and even discrepancies can be understood as something that helps to identify the meaning, the author ${ }^{1}$ of Ezra and Nehemiah intends to communicate through exactly these literary means.

1.The term 'author' is used in a very broad sense. Since we do not know exactly how the redaction process of Ezra/Nehemiah was, the term serves as a place holder for the redaction process of Ezra/Nehemiah was, the term
whoever wrote or compiled the book in its final stage.
We will now come to the book itself. We will first ask the question if these are two separate books, or if they should be understood as one literary unit.

\section{The book}

\section{Ezra and Nehemiah - One book}

Most OT scholars agree that Ezra and Nehemiah must be considered as one book. Even the Masoretes, who were responsible for the tradition and annotation of the Hebrew Bible in the Middle Ages, made this very clear. They count the number of verses for both books together and mark Nehemiah 3:32 as the middle of the whole book (Dillard \& Longman III 1994:180). There are no final remarks after the end of Ezra as we usually would expect '... and several lists count the two books as one' (Howard 1993:275). The first mention of them as two separate books can be found in Origen (around 200 AD) (Eissfeldt 1956:670). The first Hebrew edition where we really find Ezra and Nehemiah as two separate books comes from 1448 AD. The Septuagint also considered them as one book in their oldest manuscripts. In the later Septuagint editions, we find two other apocryphal books (Esdra $\alpha$ and The prophet Esdra), while the Book of Ezra is named Esdra $\beta$, and Nehemiah is named Esdra $\gamma$.

We can therefore deduce with a very high probability that Ezra and Nehemiah must be considered as one book, as one literary unit. But does 'literary unit' also mean that the story itself displays a narrative that can be understood as a whole, as a unity?

\section{The literary unity of Ezra/Nehemiah}

Many scholars have discussed the question of the chronological and the logical relationship of the story narrated in Ezra/Nehemiah. Often scholars tend to reconstruct the story, because they think the events must be brought into the 'correct order' (e.g. Batten [1913] 1949:4-5). One question that has to be answered in this regard is the question of chronology and its understanding and role in biblical narratives.

\section{The problem with chronology}

In Western societies the chronological order of things is an essential element of storytelling. This may be called an 'absolute chronology', meaning strictly to follow the chronological order of the things related in the story. Every deviation from this chronological order must be mentioned. A second element of this 'absolute chronology' is the tendency to relate every aspect of the story to a fixed chronological system (for example, 20 May 2021 AD).

Both aspects of such an 'absolute chronology' seem to be foreign for the culture and time of the Ancient Near East (as is the case for many recent cultures also). The main question here is not, when something happens, but under which circumstances or relations it happens. This could be called a 'relative chronology'. Deviations from the strict 
chronological order are possible without explicitly naming them, if this deviation seems to be necessary because of the inner logic of the story itself (Bluedorn \& Wünch 2002). This also applies to Ezra/Nehemiah.

\section{The composition of the text}

Zenger (2012:337) emphasised that there is a high internal unity, an internal logic to the book, which does not come from a strict chronological order or structure, but through selecting and putting together important historical facts and events from a period of more than 100 years. This then creates an overall picture of how Israel organised and defined itself after the exile. It may therefore be that the events must be sorted otherwise to give us a 'correct' picture of the history of this time. But if we want to see what the author of Ezra/Nehemiah tries to communicate to his readers, we need to see the narrated events exactly in the order as represented in the book. We need to look at the structure of the book and the way of storytelling, if we want to identify the meaning of the text.

This is exactly the idea of the so-called 'literaturwissenschaftliche Exegese' or literary exegesis. In a way, the discrepancies or fractures are not the problems of the text, but they can even help us understand what the author wants to convey to us. This is not just the case with narratives from the Ancient Near East. It is also an often used stylistic device in modern fictional works. Unexpected changes, things that just do not fit together, discrepancies in the narration - they are all used to intensify the tension and direct the reader in his/her reading process. Imagine if a story from Alfred Hitchcock is read in a historical critical way, and separated into different sources as soon as one comes to a statement that does not fit into the story as related until then ... We would miss the whole excitement and fun of the story!

\section{Ezra/Nehemiah and Chronicles}

Another question we have to answer concerning Ezra/ Nehemiah is its relation to Chronicles. This mainly refers to two areas: (1) is the author of Chronicles and the author of Ezra/Nehemiah the same, and (2) when did the two books become canonical? There is no place here to discuss this in any depth, but let us just make some preliminary remarks regarding these questions.

\section{Is the author of Chronicles and the author of Ezra/Nehemiah the same?}

This is a long and still on-going discussion. Jewish tradition views Ezra as the author of the whole, as we can see in Baba Batra 15a (Dillard \& Longman III 1994:180). This is not impossible, but there are only a few OT scholars, who think so today. Many scholars argue that there is a close relationship to the Book of Chronicles. The last verses of Chronicles are almost verbally identical to the introductory verses in Ezra. Often, this leads to the assumption that there is a common author (for example, Batten [1913] 1949:1; Coggins 1976:1-2; Eissfeldt 1956:670; Fohrer \& Sellin 1979:257; Sellin 1969:257; Kaiser 1969:141; Myers 1965:63-70; Rudolph 1949:22;
Smend 1978:226²), usually called the 'Chronist'. Others think that it was a group of authors working on both books. Ezra/Nehemiah is then viewed as the continuation of Chronicles (e.g. Blenkinsopp 1988:49-54). Another argument in favour of a common authorship is the fact that the apocryphal book, 1 Esdras, starts with the chapters 35-36 of 2 Chronicles (Fried 2015:3).

Recently, this presumed common authorship of Chronicles and Ezra/Nehemiah has been questioned by a growing number of scholars (e.g. Lang 2008:295; Schunck 2009:12; Venter 2018:7; Williamson 1987:23; Zenger 2012:337). Farisani (2004:208-215) wrote a very thorough analysis of the arguments pro and contra a common authorship. His conclusion is that there are undeniable differences between these books' (Farisani 2004:215). One of the arguments used in favour of different authors is the fact that Chronicles does not seem to view marriages between Jews and non-Jewish women critically, while Ezra/ Nehemiah decidedly does so.

As already stated, it is beyond the purview of this article to discuss this in any depth.

\section{When did the two books become canonical?}

It is often argued that Ezra/Nehemiah was first canonised, and thereafter Chronicles. The main argument is that Ezra/Nehemiah comes first in the canonical order of the Hebrew canon. The reason for this is seen in the fact that Chronicles mainly contains narrations, which are also to be found in other OT books (e.g. Coggins 1976:1-2; Harrison 1969:1149-1150; Kaiser 1969:141). Other scholars (e.g. Blenkinsopp 1988:39) challenge this chronological order. According to them, there is no evidence for it.

To the author it seems more probable that the place of Chronicles as the last book of the Hebrew canon must rather be seen in the fact that it is type of summary of the entire history of Israel (and even beyond Israel), and that the Book of Chronicles has some sort of an 'open end', showing the possibility of a renewal of Israel after the exile. Canonical exegetes therefore call the Book of Chronicles an 'Abschlussphänonmen' - a conclusion phenomenon - of the Hebrew canon (e.g. Steinberg 2006:77).

Before dealing with the structure of Ezra/Nehemiah, there is one other topic that should at least be touched upon: the question of the historical background of Ezra/Nehemiah. This has consequences for the understanding of the entire book and its structure.

\section{Ezra and Nehemiah and the historical background}

There is not much discussion on the question of the historical placement of Nehemiah. According to Nehemiah 1:1 and 2:1, 2.Kessler argues that the author of Chronicles at least had something to do with the composition of Ezra/Nehemiah (1971:11). 
his story starts in the year 20 of King Arthasasta, who can be identified as Artaxerxes I. This means that we are in the year 445 BC, which fits well with the extrabiblical sources. There is, for example, a letter amongst the Elephantine Papyri, which dates from the year 408 BC. Its author is the High Priest Johanan, the second to follow Eliashib, who was a contemporary of Nehemiah. The letter is addressed to the sons of Sanballat, who also were contemporaries of Nehemiah (Dillard \& Longman III 1994:182). This shows that Nehemiah could securely be assigned to the reign of Artaxerxes I (Demsky 1994:3).

More problematic is the dating of Ezra. If King Arthasasta, mentioned in Ezra 7:1-8, is the same as the Arthasasta in Nehemiah, he would also be King Artaxerxes I. This would mean that Ezra started his work around 458 BC. He would have been in Jerusalem at the time Nehemiah arrived there. So why do we not find any reference to him in the report of Nehemiah, arriving in Jerusalem?

Some exegetes think that Ezra 7 and 8 contains a text critical error and must be read as the 37th year of Arthasasta, not the 7th (e.g. Dillard \& Longman III 1994:182). This would mean that Ezra arrived in Jerusalem in the year 428 BC, maybe together with Nehemiah. In this case, the entire relationship between the Books of Ezra and Nehemiah would be different, and the narrative would have to be reconstructed.

The same would be true if King Arthasasta, in the Book of Ezra, was identified as Artaxerxes II. In this case, the work of Ezra would start in the year 398 BC, and Nehemiah and Ezra would never have met. Therefore, Nehemiah 8 would have to be considered as an historical fiction, as well as many other parts of the narrative in the entire book. The main argument for this late dating of Ezra can be found in Ezra 10:6, where we read that Ezra went into the chamber of Johanan, the son of Eliashib. According to Nehemiah 12 and 11.22-23, this same Johanan seems to be the grandson of Eliashib, not his son (which is no contradiction since the Hebrew term 'ben' can be used in this way). Eliashib was High Priest at the time of Nehemiah. So how could Ezra go into the chamber of Eliashib's grandson in the temple, if Ezra was born before Nehemiah (e.g. Dillard \& Longman III 1994:182)?

Josephus mentions a certain Jaddua, who was High Priest during the time of the invasion of Alexander the Great, which occurred approximately 370 BC. According to Nehemiah 12:22-23, Jaddua was the son of Johanan (Yamauchi 1980:9).

Edwin M. Yamauchi offered some interesting solutions to these questions. He stated that the name Johanan was a very popular name at that time. There are 14 different people in the OT with this name. In the apocryphal Book of Makkabeans, we find the name Johanan used for five different people, and Josephus knew 17 people with this name. The simple identification of the Johanan in the Book of Ezra with the Johanan who is mentioned in the work of Josephus, should be viewed critically (Yamauchi 1980:9). After discussing this and other arguments for a late dating of Ezra, Yamauchi argues to adhere to the traditional dating of Ezra, as it is also in agreement with the story in the Book Ezra/Nehemiah (Yamauchi 1980:9-12). Howard also argues for the traditional dating of Ezra, and shows how the arguments against this can be answered quite convincingly (Howard 1993:281-283; compare also, Möller 1934:262-264; Rendtorff 1984:165-166). After a long discussion of the arguments in favour of a reverse order of Ezra-Nehemiah, Yamauchi (1980) stated:

$[I] n$ summary, though the reverse order of Nehemiah before Ezra which has dominated for over two decades still has many eminent supporters, there has been within the last decade a remarkable development of support among equally distinguished scholars for the traditional order of Ezra before Nehemiah. (p. 13)

The author is in agreement with Yamauchi and others (e.g. Coggins 1976:8; Dillard \& Longman III 1994:181-182; Harrison 1969:1150; Möller 1934:262-264) in this context.

One last remark pertaining to this question: Aaron Demsky, Professor of Biblical History at Bar-Ilan University in Israel, argues that Ezra and Nehemiah use two different chronological systems. While Ezra uses the traditional counting of the months, as we also find in the Torah and among the prophets, Nehemiah uses the civil names of the months (Demsky 1994:10-11). In addition, the counting of the years is different according to Demsky. Ezra uses the priestly system of the Sabbath years, while Nehemiah counts the years according to the reign of the Persian kings (Demsky 1994:11). Demsky comes to the conclusion that Ezra came to Jerusalem in a Sabbathyear (the 'seventh' year), which would be the August of the year 443 BC, shortly before the completion of the wall (Demsky 1994:15). However, Demsky needs to change the text of Ezra 7:7-8. He believes that there is a later change of the original text, because in these verses King Arthasasta is clearly mentioned for the reckoning of the years. It therefore seems better to adhere to the traditional dating of Ezra.

We will now procced to the main part of this article: the structure of Ezra/Nehemiah.

\section{The structure of Ezra/Nehemiah}

In the discussion of the structure of Ezra/Nehemiah, we will first take a concise look at the sources, the author uses, and then come to the structure of the book.

\section{The sources}

The author of the Book clearly uses many sources. There are different lists of the returnees or people working at the wall, the historical reports of the first six chapters, and the autobiographical reports of Ezra and Nehemiah, to name just a few of the most important ones.

The combination of these sources leads to three major parts of the Book. Ezra 1-6 narrates events, starting about 
100 years prior to Ezra or Nehemiah. Ezra 7-10 relates the deeds of Ezra with the emphasis on the building of the temple in Jerusalem. The Book of Nehemiah finally speaks about the deeds of Nehemiah with the emphasis on the building of the wall. This is a very rough structure following the historical related events. A closer look will show a much more complex structure.

\section{The structure}

When we look for the author-intended structure, we should keep in mind that, although we are looking at a written text, this text was meant to be used in an oral context. This seems to be true for all biblical texts. They were meant to be read to an audience. Any structural elements the author wants to present to his audience must consequently be something the listener could identify. In this way, the unexpected elements in a text do play a major role for the conveyance of the intended message of the book. Things the listener did not expect are an important means to highlight special structural elements. Stefano Cotrozzi has shown this convincingly in his doctoral thesis: Expect the Unexpected: Aspects of Pragmatic Foregrounding in Old Testament Narratives (Cotrozzi 2010). When it comes to Ezra/Nehemiah, one major aspect of these 'unexpected elements' are the many lists of names the book contains, and their function for the structure of the book. In this regard, we will also discuss the differences between the two lists of returnees in Ezra 2 and Nehemiah 7. Other unexpected elements are the Aramaic passages in the book and the autobiographical notes. Can these elements or some of them be understood as part of a deliberately constructed literary unit? In this article, we will focus on the two list of returnees and their function for the structure of the Book.

\section{The different lists as structural elements}

Eskenazi (1988) presents a very interesting proposition. She understands the many lists in the Book as structural elements. Roughly $25 \%$ of the Book consists of lists. They not only serve the structuring of the Book, but also show how the reported events and the deeds of special people such as Ezra or Nehemiah become very important for the people of Israel as a whole. The lists therefore enable the narration of the deeds of Ezra, Nehemiah and others, to be part of the history of the nation (Eskenazi 1988:642).

The repetition of the list of returnees in Ezra 2 and Nehemiah 7, plays a major role. Eskenazi understands this as an inclusion, marking the events narrated in between as the central part of the Book. This central part consists of three compact units. The first relates the story of Zerubbabel and Jeschua, and the building of the temple in Jerusalem. The second unit narrates the story of Ezra, and how the post-exilic Israel was rebuilt according to the requirements of the Torah. The final unit tells us about Nehemiah and how he, together with the Jews in Jerusalem, rebuilt the wall of the town (Eskenazi 1988:646-647).

This leads to three major structural parts of the book: Ezra 1 serves as introduction, presenting the main topic of the entire book: King Cyrus calls the people of Israel to rebuild the house of the Lord in Jerusalem. Then follows the detailed record of how this command was implemented (Ezr. 2; Neh. 7). Finally, people celebrate the success and the covenant is reinstalled in the new temple (Neh. 8-13). The Book therefore starts with the command to build the temple and ends with the report of the fulfilment of this command (Eskenazi 1988:647).

According to Eskenazi (1988:650-651), the structure of the main part of the Book can then be shown as a chiastic one.

A Introduction: The edict of King Cyrus (Ezr. 1)
B $\quad \begin{aligned} & \text { Main part: The edict fulfilled (Ezr. 2 - Neh. 7) } \\ & \text { B1 }\end{aligned}$
B2 The list of returnees (Ezr. 2)
The outer construction: The temple rebuilt
(Ezr. 3-6)
The inner construction: The law reinforced
(Ezr. 7-10)
B2' $\quad$ The outer construction: The wall rebuilt
(Neh. 1-7:4)
B1' The list of returnees (Neh. 7:5-72)
Conclusion: The covenant reinstalled, the celebration
of the outer construction, and the consolidation of
the inner construction (Neh. 8-13)

This structure shows that the construction of the inner structure of the people of Israel (the proclamation and consolidation of the Torah and the covenant) is in the centre of the entire Book, while the outer construction (the temple and the wall) presents the necessary framework.

Another way to structure the Book has recently been proposed by Zenger (2012:336). He understands the Book is divided into three sections corresponding with each other. In each section there is always a part $A$, where we read about the outer reconstruction and then a part $B$, where this is complemented with a report of the inner reconstruction:
A The temple rebuilt against opposition (Ezr. 1-6)
B The commitment to the law/covenant (Ezr. 7-10)
A' The wall rebuilt against opposition (Neh. 1-7:4)
B' The commitment to the law/covenant (Neh. 7:5-10)
A" The completion of the rebuilding (Neh. 11-12)
B" The enforcement of the covenant (Neh. 13)

Both structures act on the assumption that the book as a whole was constructed as a literary unit and that the author consciously presents the events in this way. They are not mutually exclusive, but can be understood as complementary. We could therefore propose the following structure of the book: 
A The temple rebuilt against opposition (Ezr. 1-6) ${ }^{3}$

Introduction (Ezr. 1)

The list of returnees (Ezr. 2)

The outer construction: The temple rebuilt (Ezr. 3-6)

B The commitment to the law/covenant (Ezr. 7-10) The inner construction: The law/covenant reinforced

A' The wall rebuilt against opposition (Neh. 1-7:4)

The outer construction: The wall rebuilt (Neh. 1-7:4)

The list of returnees (Neh. 7:5-72)

B' The commitment to the law/covenant (Neh. 8-13)

The covenant reinstalled (Neh. 8-9)

The covenant document (Neh. 10)

The populating of the town and the province (Neh. 11)

The workers at the temple and the consecration of the wall (Neh. 12)

Conclusion and consolidation of the covenant (Neh. 13)

The list of returnees in Nehemiah 7 belongs to both: $\mathrm{A}^{\prime}$ and $\mathrm{B}^{\prime}$, working as some kind of hinge between them. As in the structure presented by Eskenazi, these lists serve as an inclusion, highlighting the central elements of the story in between these lists.

Besides the two lists of returnees, we find many other lists in Ezra/Nehemiah:

- the list of the vessels for the temple (Ezr. 1:9-11),

- the list of the companions of Ezra (Ezr. 8:1-14),

- the list of men, who divorced their heathen wives (Ezr. 10:18-44),

- the list of those working together in rebuilding the wall (Neh. 3:1-32),

- the list of those who signed the covenant (Neh. 10:2-29),

- the list of the Jews living in the country (Neh. 11:3-36),

- the list of Priests and Levites (Neh. 12:1-26), and

- the list of those who took part in the consecration of the wall (Neh. 12:32-42).

As already mentioned, these lists serve to link the special deeds of some important people such as Ezra and Nehemiah to the everyday people, living in Israel. They show that it is not just about these special people and their importance, but that Israel as a whole needs to be God's holy people, serving him.

\section{The differences in the lists of returnees}

One of the main difficulties in the interpretation of Ezra/ Nehemiah is the fact that the two extensive lists of returnees in Ezra 2 and Nehemiah 7 are almost the same, but they are

3.Chapters $1-6$ of course do not present a full account of everything that happened in the roughly 100 yers after the edict of King Cyrus. Fensham (1982:4-5) pointed out the roughly 100 years after the edict of King Cyrus. Fensham (1982:4-5) pointed out that 'the author recorded only certain instances which he regarded as important fo understanding Jewish religious development in this period. Of primary importance for his purpose are those selected facts which emphasize the continual Samaritan opposition to the reconstruction of Jewish religious life and the reorganization of the religious community by the building of an altar and the eventual reconstruction of the temple'. not identical. The introduction to both lists in Ezra 2:1 and Nehemiah 7:7 is almost verbatim. However, there are differences.

Many scholars either ignore these differences or they argue that they are because of the use of different sources and that the differences are proof for the historical unreliability of the text. But if the lists are used purposefully as structural elements, as shown above, we should not think that the author did not notice the differences. It is therefore important to ask how these differences can be explained.

One major point of difference concerns the numbers. The overall number of returnees is identical in both lists (42.360: Ezr. 2:66 and Neh. 7:64), and the number of slaves, horses, mules, camels and donkeys is the same (Ezr. 2:67-68 and Neh. 7:65-67). Only the number of singers differs, but this could be a text critical problem. It could be that the number 45 was skipped, because in the next verse, we read about 245 mules.

However, there are also differences found in the lists. There are many ideas as to how these differences can be explained or harmonised. Basically, we should notice that in the process of copying biblical texts, the numbers in these texts are prone to errors. For example, if one reads the number 2456 and then writes 2465, this does not directly alter the meaning. When writing a story, deviations from the story can easily be identified, whilst deviations from numbers cannot. Part of the problem with the different numbers in the two lists of returnees may therefore be that textual errors came into the text in the process of the tradition.

Another possible solution for the differences between the numbers of the returnees in Ezra and those in Nehemiah, is that Ezra presents the number of those who left Babylon, whilst Nehemiah presents the number of those who arrived in Jerusalem. It might well be that some, who started the trip from Persia to Israel, turned back during the voyage. Others may have joined the returnees on their journey from Babylon to Israel. This would explain that not all numbers are lower in the second list. Redditt (2012:223-224) thinks that the author thereby wants to declare that not everyone who counted himself as part of the post-exilic Israel really belonged to it.

We should also note that in neither list, the total number given (42.360) is reached. If one adds the numbers in Ezra 2, it only sums up to 29.818 returnees, while the addition in Nehemiah adds up to 31.089. In Ezra, about 11.500 people are missing; in Nehemiah it is roughly 11.000. These differences cannot be explained solely by scribal mistakes. On the other hand, the author of Ezra/Nehemiah must have noted them. They cannot simply just be mathematical mistakes. A reason for the differences could be that there were a number of people who were not able to name their family origin. They would therefore not be counted as members of any family in the list, but would nevertheless be part of the final number. 
The total number (42.360) in both lists would then be the number of all the people who finally arrived in Jerusalem.

It therefore seems that the list in Ezra 2 was compiled in Babylon and contains the Jews, who decided to follow the call to return to Israel, while the total number of the returnees, who arrived in Jerusalem, was added to this list later. Nehemiah starts his list in Nehemiah 7 with the report that God called him to gather the people of Jerusalem and to write their names into family registers. For this reason, he used and revised the list of those who came to Jerusalem from Babylon. The Ezra list would therefore contain the list of those who left Babylon, while the Nehemiah list would contain those who finally reached Jerusalem.

However, the differences in the lists should not be used to challenge the historicity of the lists. On the contrary, the differences even speak in favour of a historical reliability. The author did not see any reason to harmonise the two lists, which obviously came from two different sources. It seems that the way the author treated these two lists and their apparent differences, shows the precision of work the author exerts.

\section{The Aramaic passages}

One of the specialities of Ezra/Nehemiah is the fact that we do find longer Aramaic passages, something which outside of the Book - can only be found in the Book of Daniel. Aramaic was the official language of the Assyrian, Babylonian, and Persian empires. Besides the Canaanite languages (which includes Hebrew), it is one of the major Semitic languages. After the destruction of Jerusalem and the temple in $568 \mathrm{BC}$, and the deportation into exile, Aramaic increasingly became the everyday language of the Jews. Hebrew was still in use, but Aramaic was the language used in most cases of everyday life.

Later, Hebrew shows a lot of Aramaic influences, although the exact definition of what really can be called 'Aramaism' is difficult. In the following centuries, Aramaic became the major language used in Israel, while Hebrew became the language of the cult and was mainly used in the synagogue. In the times of Ezra and Nehemiah, it must be concluded that both languages were well known and used.

The Aramaic texts in Ezra/Nehemiah are found in Ezra 4:8-6:18 and 7:12-26. The first passage contains the letter that several of the enemies of the Jews wrote to the King in Babylon and the response of the king. As Aramaic was the official language of the state, the reason for this seems to be clear. The subsequent verses report the reaction to the King's letter (found in chapter 4). We then hear about the prophets Haggai and Zechariah. Then follows the letter of Tattenai to King Darius, and the response of King Darius with a repetition of the original degree of King Cyrus. Finally, we hear about the reaction of Tattenai and his friends, and the completion of the temple and its dedication.
The second Aramaic passage in 7:12-26 contains the official letter that King Artaxerxes gave to Ezra for his voyage to Israel.

It seems reasonable that all the official documents (letters) narrated in these verses are Aramaic. But why does this also apply to the narrative texts in between? Maybe the reason is that switching between Aramaic and Hebrew should be avoided and vice versa. It could also be that the author used an Aramaic source. What can be shown with some certainty is that the language used in the letters cited in Ezra/ Nehemiah perfectly fits with the language we find in official documents from these times. The fact that the Aramaic shows some Hebrew influence should also be expected. This is evident especially since, according to Hugh Godfrey Williamson, many Jews worked in the Persian administration. Therefore, it seems logical that Jews were used when decrees or letters concerning their people had to be formulated (Williamson 1987:32-33).

A problem exists in Ezra 4, where we find the letter to Artaxerxes and his reply. While the passage of Ezra 1-6 as a whole deals with the building of the temple, this letter speaks about the building of the wall. A second problem is that Artaxerxes only became king after Darius, who is addressed in chapters 5 and 6 . It seems clear that these chapters do not follow a clear chronological order. Blenkisopp notes that 'this compositional technique is by no means rare in ancient historiography, and the editor has alerted us to it by the resumptive verse 4:24, ...' (Blenkinsopp 1988:43). Fried (2012:12-14) quotes a number of possible solutions to this problem. It may be that the order sorts the events starting from the negative to the positive. It could also be that the letters are used to show the different methods the officials responsible for Jerusalem and the surrounding area used to hinder God's plan, and that there is no chronological order intended. In this way, they bridge the gap between Ezra 1-3 and Ezra 7. Finally, another reason could also be that the letters in Ezra 4-6 are used to prove that it was right to deny the people living in Juda and Jerusalem the possibility to work together with the returnees in building the temple.

\section{The autobiographical passages}

Another speciality of Ezra/Nehemiah are the manifold autobiographical passages. There is an ongoing discussion whether or not these autobiographical passages were written by Ezra resp. Nehemiah themselves. For example, Coggins (1976:4) argues that the autobiographical Nehemiah-texts were rather written by someone who wanted to honour Nehemiah. But he does not give any arguments for his position. Others think that these autobiographical passages are at least mainly autobiographical, but there are also no compelling arguments for this position either. The author therefore adheres to the idea that these passages go back to reports from Ezra and Nehemiah to King Artaxerxes. Both Ezra and Nehemiah speak in the first person, when they tell about what they did experience. This is, as Kessler (1971:12) noted, 'neu im biblischen Schrifttum'. There are different terms 
for these passages being used in OT research. Often we read about memoires or (especially with Nehemiah) about a memorial (Denkschrift) or votive (Votivschrift) (e.g. Von Rad 1971:297-298). As every one of these different terms conveys certain modern concepts, it seem better to just speak about autobiographical passages.

These passages are Ezra 7:27-8:34 and 8:39-9:15 (possibly also 8:35-36). The changes between the autobiographical passages and the narratives in the third person are quite abrupt. The autobiographical passages in Nehemiah are chapters 1 and 2, and the passages 4:1-7:5. In the latter part of the book, we also find short passages, where the ' $\mathrm{I}$ ' or the 'We' is used, but they do not form any coherent block. Nehemiah 3 interrupts the autobiographical passage with the list of those who helped build the wall. In chapter 7, the autobiographical passage ends with the list of returnees.

One can easily see that a major part of the main narrative in Ezra 2 to Nehemiah 7 is formed by the autobiographical notes of Ezra and Nehemiah. It may be that the sources used in formulating these narratives were accounts Ezra and Nehemiah had to send back to Babylon at the end of each year of activity to inform King Artaxerxes about their work. These reports were then later edited and reworked, maybe even by Ezra or Nehemiah. This especially refers to the so called 'remember me' sections in Nehemiah.

Dillard and Longman III (1994:186) think that the autobiographical reports present a more subjective, personal view, while the reports in the third person are a more objective and authoritative assessment of the events. This would give the reader a way to evaluate the events. According to them, the author usually confirms Ezra and his deeds, while he shows some critique when it comes to Nehemiah, and especially the parts where he seems to boast about, and praise himself (p. 186).

\section{Conclusion}

This article wanted to show that it is possible to understand the Book of Ezra/Nehemiah in its present form as a literary unit with an inner unity. The author is aware that there are still many questions to answer. For example, how the presented structure could possibly be connected with the sources, autobiographical sections, or the Aramaic parts of the book? Is there any connection between these beyond what was said in this article? There are of course other ways to structure the Book as a whole, as a literary unit. This article aimed to present an interesting attempt to understand how the two long lists of returnees can be seen as a major aspect of the logical structure of Ezra/Nehemiah.

\section{Acknowledgements Competing interests}

The author declares that he has no financial or personal relationships that may have inappropriately influenced him in writing this article.

\section{Author's contributions}

H-G.W. is the sole author of this article.

\section{Ethical considerations}

This article followed all ethical standards for research without direct contact with human or animal subjects.

\section{Funding information}

This research received no specific grant from any funding agency in the public, commercial or not-for-profit sectors.

\section{Data availability}

Data sharing is not applicable to this article as no new data were created or analysed in this study.

\section{Disclaimer}

The views and opinions expressed in this article are those of the author and do not necessarily reflect the official policy or position of any affiliated agency of the author.

\section{References}

Alter, R., 2011, The art of biblical narrative, New and revised edn., Basic Books, New York, NY.

Bar-Efrat, S., Menzel, K. \& Naumann, T., 2006, Wie die Bibel erzählt: Alttestamentliche Texte als literarische Kunstwerke verstehen. Dt. Erstausg., 1. Aufl, Gütersloher Verlagshaus, Gütersloh.

Batten, L.W. [1913] 1949, A critical and exegetical commentary on the Books of Ezra and Nehemiah, The International Critical Commentary, T. \& T. Clark, Edinburgh.

Blenkinsopp, J., 1988, Ezra - Nehemiah: A commentary, The Old Testament Library, The Westminster Press, Philadelphia, PA.

Bluedorn, W. \& Wünch, H.-G., 2002, 'Chronologie im Alten Vorderen Orient und im Alten Testament', in H. Pehlke (Hg.), Zur Umwelt des Alten Testaments, HänsslerHardcover, Bd. Erg.-Bd. 1Bd, pp. 264-289, Hänssler, Holzgerlingen.

Coggins, R.J., 1976, The Books of Ezra and Nehemiah, The Cambridge Bible Commentary, Cambridge University Press, Cambridge.

Cotrozzi, S., 2010, Expect the unexpected: Aspects of pragmatic foregrounding in Old Testament narratives, Library of Hebrew Bible / Old Testament Studies: 510, T\&T Clark, New York, NY.

Demsky, A., 1994, 'Who came first, Ezra or Nehemiah?: The synchronistic approach', Hebrew Union College Annual 65, 1-19.

Dillard, R.B. \& Longman III, T., 1994, An introduction to the Old Testament, Zondervan Publishing House, Grand Rapids, MI.

Eissfeldt, O., 1956, Einleitung in das Alte Testament: Unter Einschluß der Apokryphen und Pseudepigraphen sowie der apokrypen- und pseudepigraphenartigen Qumran-Schriften. Entstehungsgeschichte des Alten Testaments. 2., Neue Theologische Grundrisse, völlig neubearbeitete Auflage, Verlag J. C. B. Mohr (Paul Siebeck), Tübingen.

Eskenazi, T.C., 1988, 'The structure of Ezra-Nehemiah and the integrity of the book', JBL 107(4), 641-656. https://doi.org/10.2307/3267626

Farisani, E.B., 2004, 'The composition and date of Ezra-Nehemiah', OTE 17(2), 208-230.

Fensham, F.C., 1982, The books of Ezra and Nehemiah, The New International Commentary on the Old Testament, Eerdmans, Grand Rapids, MI.

Fohrer, G. \& Sellin, E., 1979, Einleitung in das Alte Testament. 12., überarbeitete und erw. Aufl, Quelle \& Meyer, Heidelberg.

Fried, L.S., 2012, 'Ezra's use of documents in the context of Hellenistic rules of rhetoric', in I. Kalimi (Hg.), New perspectives on Ezra-Nehemiah: History and historiography, text, literature, and interpretation, pp. 11-26, Eisenbrauns, Winina Lake, IN.

Fried, L.S., 2015, Ezra: A commentary, Sheffield Phoenix Press, Sheffield.

Harrison, R.K., 1969, Introduction to the Old Testament: With a comprehensive review of Old Testament studies and a special supplement on the Apocrypha, Eerdmans, Grand Rapids, MI.

Howard, D.M., 1993, An introduction to the Old Testament historical books, Moody Press, Chicago, IL.

Kaiser, O., 1969, Einleitung in das Alte Testament: Eine Einführung in ihre Ergebnisse und Probleme, Gütersloher Verlagshaus Gerd Mohn, Gütersloh. 
Kessler, W., 1971, Gottes Mitarbeiter am Wiederaufbau: Die Propheten Esra und Nehemia. übersetzt und ausgelegt von Werner Kessler, Die Botschaft des Alten Testaments, Bd. 12, IVBd, Calwer Verlag, Stuttgart.

Lang, A., 2008, “'Eure Töchter gebt nicht ihren Söhnen und ihre Töchter nehmt nicht für eure Söhne" (Esra 9,12): Die Frage der Mischehen im Buch Esra / Nehemia im Licht der Textfunde von Qumran', in B. Janowski (eds.), Was ist der Mensch, dass du seiner gedenkst? (Psalm 8,5): Aspekte einer theologischen Anthropologie; Festschrift für Bernd Janowski zum 65. Geburtstag pp. 295-311, Bauks, M., Hrse. Neukirchen-Vluyn.

Möller, W., 1934, Einleitung in das Alte Testament. Herausgegeben in Verbindung mit Lic. Grete Möller und Lic. Hans Möller, Verlag von Johannes Herrmann, Zwickau.

Myers, J.M., 1965, Ezra Nehemiah: Introduction, translation, and notes, The Anchor Bible, 14, Doubleday \& Company, Garden City, NY.

Redditt, P.L., 2012, 'The census list in Esra 2 and Nehemiah 7: A solution', in I. Kalim (Hg.), New perspectives on Ezra-Nehemiah: History and historiography, text, literature, and interpretation, pp. 223-240, Eisenbrauns, Winina Lake, IN.

Rendtorff, R., 1984, 'Esra und das “Gesetz"', ZAW 96(2), 165-184. https://doi. org/10.1515/zatw.1984.96.2.165

Rudolph, W., 1949, Esra und Nehemia: samt 3. Esra, Handbuch zum Alten Testament, 20, Verlag J. C. B. Mohr, Tübingen.

Schunck, K.-D., 2009, Nehemia, Biblischer Kommentar. Altes Testament, Bd. Bd. 23/2Bd, Neukirchener Verlag, Neukirchen-Vluyn.
Sellin, E., 1969, Einleitung in das Alte Testament. Begründet von Ernst Sellin, neubearbeitet von Georg Fohrer, o. Professor an der Universtität Erlangen-Nürnberg. 11 , durchgesehene und erweiterte Auflage, Quelle \& Meyer, Heidelberg.

Smend, R., 1978, Die Entstehung des Alten Testaments, Theologische Wissenschaft Sammelwerk für Studium und Beruf, 1, W. Kohlhammer, Stuttgart.

Steinberg, J., 2006, Die Ketuvim: Ihr Aufbau und ihre Botschaft, Bonner Biblische Beiträge, 152, Philo, Hamburg.

Utzschneider, H. \& Nitsche, S.A., 2014, Arbeitsbuch literaturwissenschaftliche Bibelauslegung: Eine Methodenlehre zur Exegese des Alten Testaments. 4. vollständig überarbeitete und ergänzte Auflage, Gütersloher Verlagshaus, Gütersloh.

Venter, P.M., 2018, 'The dissolving of marriages in Ezra 9-10 and Nehemiah 13 revisited', HTS Teologiese Studies/Theological Studies 74(4), 1-13. https://doi. org/10.4102/hts.v74i4.4854

Von Rad, G., 1971, Gesammelte Studien zum Alten Testament. 4. Aufl, Theologische Bücherei, 8, Kaiser, München.

Williamson, H.G., 1987, Ezra and Nehemiah, Old Testament guides, JSOT for the Society for Old Testament Study, Sheffield.

Yamauchi, E.M., 1980, 'The reverse order of Ezra/Nehemiah reconsidered', Themelios 5(3), 7-13.

Zenger, E., 2012, Einleitung in das Alte Testament. 8., Kohlhammer-Studienbücher Theologie, Bd. 1, vollst. überarb. Aufl, Kohlhammer, Stuttgart. 